\title{
Effect of experimental fascioliasis on the protein synthesis function of cow liver
}

\author{
O. Kulyaba, V. Stybel, B. Gutyj, I. Turko, R. Peleno, Ya. Turko, P. Golovach, V. Vishchur, \\ O. Prijma, I. Mazur, V. Dutka, V. Todoriuk, O. Golub, O. Dmytriv, R. Oseredchuk
}

\author{
Stepan Gzhytskyi National University of Veterinary Medicine and Biotechnologies \\ Lviv, Ukraine. E-mail: bvh@ukr.net
}

Received 13.10.2019 Accepted 10.12.2019

\begin{abstract}
The purpose of the work was to explore the indicators of functional state and function of protein synthesis of the cow liver within experimental fasciolysis, sensitized to atypical mycobacteria. Ten cows of black-and-white breed were selected for the experiments. Two groups consisting of five animals each were formed. The control group cows were clinically healthy. The animals of the experimental group were contaminated with mycobacteriosis and fascicular invasion. In the course of research, the rules for performing zootechnical experiments on the selection and maintenance of animal-analogues in the group, harvesting technology, use and accounting of consumed feed were followed. Being impacted by fascicular invasion, the cattle sensitized with mycobacteria demonstrated the suppression of the liver protein synthesis function, which manifests itself as a decrease in total blood protein, a decrease in the level of albumins and an increase in the level of globulins. According to the clinical manifestation of fasciolosis in the cattle sensitized with atypical mycobacteria, disease pathogens have a toxic effect on hepatocytes causing an increase in the permeability of the biological membranes of the cell membranes. The indicated changes lead to an increase in the activity of blood serum enzymes, in particular, aminotransferases (AsAT and AIAT) and alkaline phosphatase. High activity of AIAT and AsAT in the blood serum of the cows under experimental fasciolysis sensitized by atypical mycobacteria, indicates destructive processes in the liver that cause release of aminotransaminases from cellular organelles in the blood of the cattle. Thus, the results obtained indicate an increase in destructive processes in the body of the cows under experimental fascioliasis sensitized with atypical mycobacteria.
\end{abstract}

Key words: Albumin; Aminotransferase; Fasciolysis; Mycobacterium; Liver; Total protein; Globulins

\section{Introduction}

Taking into account the tense epizootic situation regarding fasciculosis of cattle in Ukraine and a significant economic and social problem (Dovgij et al., 2000; Kuljaba et al., 2016; Kulyaba et al., 2017; Gorobey et al., 2018), further in-depth study of the peculiarities of the invasion spread, the determination of the pathogenic effect of helminths on the organism of animals, the improvement of lifelong diagnosis and the development of an effective treatment scheme for animals are required. This problem remains relevant these days and it has an important national and economic significance.

The reports in the national and foreign literature indicate that, along with trematode infection of the cattle, which is registered at farms, the most widely spread if mycobacteriosis (Vejsfeller, 1975; Kravciv et al., 2007; Litvinov et al., 2008). The causative agents of mycobacteriosis of animals are so-called potentially pathogenic mycobacteria ("atypical", anonymous or unclassified) characterized by a wide range of natural drug resistance (Litvinov et al., 2010; Tkachenko et al., 2016).

Mycobacteriosis usually develops only in the attenuated body of animals previously damaged by any adverse environmental effects or the various diseases progression, including parasitic ones (Skrypnik, 2007). Despite the large number of research dealiong with the study of fasciolosis and mycobacteriosis in the cattle, such issues as epizootiology, biology, therapy, and preventive measures require new approaches. Most of the studies on Fasciola and mycobacteria biology are one-sided; they do not take into consideration their influence on the immune status and metabolism of animals.

The aim of the research was to investigate the indicators of the functional state and protein synthesis function of the liver of the cattle under experimental fascioliasis, sensitized to atypical mycobacteria.

\section{Material and Methods}

In order to conduct experiments ten cows of black-and-white breed were selected. Two groups were formed of them, five animals in each. The control group cows were clinically healthy. Animals of the experimental group were infected with mycobacteriosis and Fasciola invasion. In the course of research, the rules for performing zootechnical experiments on the selection and maintenance of animal-analogues in the group, harvesting technology, use and accounting of consumed feed were followed. The animals' diet was balanced with nutrients and minerals that ensured their need for basic nutrients.

Blood for analysis was taken from the jugular vein before infection and then on the 7th, 14th, 21st, and 28th days of the experiment. In the blood serum, the activity of aspartate aminotransferase (AsAT) (KF 2.6.1.1.) and alanine aminotransferase (AIAT) (KF 2.6.1.2.) was explored using the method of Reitman and Frenkel, in the modification of K. G. Capetanaki; alkaline phosphatase activity was determined photocolorimetrically, based on the determination of the amount of phenol released by the hydrolysis of disartrifenol phosphate. The liver protein synthesis function was determined by the level of total protein in blood serum (using the biuret reaction) and the protein fractions (using electrophoresis in the polyacrylamide gel) (Vlizlo, 2012). The analysis of 
the research results was carried out using the software package Statistica 6.0. The probability of differences was estimated Student's t-test. We used ANOVA to determine the significance of the means, $\mathrm{P}$ values with the star attached to indicate $P<0.05$, two stars to indicate $P<0.01$, and three stars were used to indicate $<0.001$. The data in tables presented as mean and standard deviation.

\section{Results and Discussion}

The state of protein synthesis function of the liver was studied at the level of total protein - an indicator of protein metabolism, which reflects the total content of all proteins in the serum. Plasma proteins are divided into groups with different structures and functions called protein fractions (Martyshuk et al., 2016; Gutyj et al., 2017). Albumins and alpha, beta, gamma globulins are among the protein fractions. Their definition and correlation allows to more accurately estimate a violation of functions of viscera (Khariv \& Gutyj, 2016). Finding the total protein level in blood is one of the ways to assess the physical condition of animals (Gutyj et al., 2016). The total protein test shows the amount of protein in the blood serum. As a rule, the level of total protein or the change of some types of globulins associated with the development of a number of diseases is studied. It helps to diagnose the issue, track changes in health, and indicates the need for other tests. In our experiments (Table 1), it was established that the cows under experimental fascioliasis sensitized with atypical mycobacteria, the total serum protein level was reduced. On the 14th and 21 st day of the experiment, a decrease in the total protein level was set at 9 and $11 \%$ relative to the control group. The content of two main groups of proteins, albumin and globulin, was quantitatively evaluated. While exploring the protein fractions, it was found out that the level of albumins in the blood of the control group cows was $43.2 \pm 1.0 \mathrm{~g} \mathrm{~L}^{-1}$, whereas in the experimental group cows it decreased to $31.2 \pm 1.1 \mathrm{~g} \mathrm{~L}^{-1}$. On the 28th day of the experiment, an insignificant increase in the albumin fraction was determined. Thus, the cattle under experimental fascioliasis sensitized with atypical mycobacteria, demonstrated suppressed synthesis of albumins in the liver due to the action of toxins that secrete Fasciola and mycobacteria.

Table 1. Content of total protein and its fractions in blood serum of the cows under experimental fascioliasis sensitized to atypical mycobacteria $(n=5)$.

\begin{tabular}{lcccccc}
\hline \multicolumn{1}{c}{ Indicator } & $\begin{array}{c}\text { Groups } \\
\text { of } \\
\text { animals }\end{array}$ & $\begin{array}{c}\text { Before } \\
\text { infection }\end{array}$ & \multicolumn{4}{c}{ Time of experiment (days) } \\
Total protein, $\mathrm{g} \mathrm{L}^{-1}$ & $\mathrm{C}$ & $70.1 \pm 1.4$ & $70.2 \pm 1.2$ & $70.4 \pm 1.4$ & $70.1 \pm 1.3$ & $70.2 \pm 1.1$ \\
& $\mathrm{E}$ & $70.1 \pm 1.2$ & $68.0 \pm 1.1$ & $63.7 \pm 1.2^{* *}$ & $62.2 \pm 1.5^{* *}$ & $63.9 \pm 1.3^{* *}$ \\
Albumin, $\mathrm{g} \mathrm{L}^{-1}$ & $\mathrm{C}$ & $43.2 \pm 1.0$ & $43.4 \pm 1.1$ & $43.5 \pm 1.3$ & $43.3 \pm 1.1$ & $43.4 \pm 1.2$ \\
& $\mathrm{E}$ & $43.4 \pm 1.2$ & $38.2 \pm 1.2^{*}$ & $34.5 \pm 1.2^{* * *}$ & $31.2 \pm 1.1^{* * *}$ & $33.7 \pm 1.0^{* * *}$ \\
Globulin, $\mathrm{g} \mathrm{L}^{-1}$ & $\mathrm{C}$ & $26.9 \pm 1.5$ & $26.8 \pm 1.3$ & $26.9 \pm 1.40$ & $26.8 \pm 1.3$ & $26.8 \pm 1.2$ \\
& $\mathrm{E}$ & $26.7 \pm 1.4$ & $29.9 \pm 1.3$ & $29.3 \pm 1.30$ & $31.1 \pm 1.7^{*}$ & $30.3 \pm 1.4^{*}$ \\
A/G ratio & $\mathrm{C}$ & 1.6 & 1.6 & 1.6 & 1.6 & 1.6 \\
& $\mathrm{E}$ & 1.6 & 1.3 & 1.2 & 1.0 & 1.1 \\
\hline
\end{tabular}

Along with the decrease in the albumin level in the blood serum of the cows, the level of the globulin fraction of the protein increased, which on the 21st day of the experiment was $31.1 \pm 1.7 \mathrm{~g} \mathrm{~L}^{-1}$, i.e., it increased by $16 \%$. These proteins are known to bind to hemoglobin. They create complexes with metals (e.g. iron) and transport them, as well as fight infections. Increasing the level of globulins in the serum of the cows under the association of fascioliasis and mycobacteriosis reflects the intensity of inflammatory processes in the animal body caused by the pathogens of these diseases. The cows under experimental fascioliasis sensitized with atypical mycobacteria, undergo albumin and globulin disproportion in the blood serum of the diseased cows. As a result, the A/G ratio was 1.0 versus 1.6 in clinically healthy cows. Such a magnitude of the ration definitely indicates the inhibition of protein synthesis function of the liver of the cow. Increase in the level of globulins in the blood serum of the cows reflects the intensity of inflammatory processes in their body. The liver in the animal body performs a number of important functions. The liver has a large number of various biochemical reactions, for which it is called the "biochemical factory of the organism" (Khariv et al., 2016; Lavryshyn et al., 2018; Ostapyuk \& Gutyj, 2018). Consequently, a large number of enzymes are synthesized or operate in the liver, and, according to their activity, the conclusion about the state of the body can be made (Khariv et al., 2017; Shcherbatyy et al., 2017). We evaluated the functional state of the liver of the cows under experimental fascioliasis sensitized with atypical mycobacteria by activity of aminotransferases, namely: alanine and aspartate aminotransferases (Nazaruk et al., 2015; Kryshtalska et al., 2017). The activity of alanine aminotransferase in the serum of the cows under experimental fascioliasis, sensitized with atypical mycobacteria, is presented in Table 2. It has been established that the cows under experimental fascioliasis sensitized with atypical mycobacteria demonstrate an increase in the activity of alanine aminotransferase in the blood, which is caused by an increase in the permeability of cell membranes and the release of this enzyme in the bloodstream. In comparison with the control group of cows, the activity of alanine aminotransferase in the experimental group of cows on the 7th and 14th days of the experiment increased by 14 and $22 \%$ relatively to the control group of cows. On day 21 of the experiment, the activity of the enzyme to be studied was the highest and, accordingly, amounted to $212.5 \pm 10.5$ nkat $\mathrm{L}^{-1}$.

Table 2. Enzyme activity in blood serum of the cows under experimental fascioliasis sensitized to atypical mycobacteria ( $n=5)$.

\begin{tabular}{|c|c|c|c|c|c|c|}
\hline \multirow{2}{*}{ Indicator } & \multirow{2}{*}{$\begin{array}{c}\text { Groups of } \\
\text { animals }\end{array}$} & \multirow{2}{*}{ Before infection } & \multicolumn{4}{|c|}{ Time of experiment (days) } \\
\hline & & & 7 & 14 & 21 & 28 \\
\hline \multirow{2}{*}{ AlAT, nkat $L^{-1}$} & C & $160.0 \pm 10.5$ & $160.5 \pm 10.1$ & $160.9 \pm 10.0$ & $161.0 \pm 10.2$ & $160.7 \pm 10.3$ \\
\hline & $E$ & $160.3 \pm 10.2$ & $182.5 \pm 10.5$ & $196.4 \pm 10.2^{*}$ & $212.5 \pm 10.5^{* *}$ & $200.3 \pm 10.0 *$ \\
\hline \multirow{2}{*}{ AsAT, nkat $L^{-1}$} & C & $270.2 \pm 16.1$ & $269.7 \pm 13.4$ & $270.0 \pm 16.2$ & $270.9 \pm 15.1$ & $270.6 \pm 14.4$ \\
\hline & $\mathrm{E}$ & $272.2 \pm 17.4$ & $297.4 \pm 15.1$ & $306.2 \pm 15.9$ & $330.8 \pm 15.0 *$ & $302.5 \pm 13.6$ \\
\hline \multirow{2}{*}{ Alkaline phosphatase, Un $\mathrm{L}^{-1}$} & C & $42.5 \pm 1.5$ & $42.1 \pm 1.1$ & $42.4 \pm 1.3$ & $42.3 \pm 1.4$ & $42.2 \pm 1.1$ \\
\hline & $\mathrm{E}$ & $42.3 \pm 1.2$ & $45.6 \pm 1.2^{*}$ & $48.3 \pm 1.2^{*}$ & $50.1 \pm 1.4 * * *$ & $48.8 \pm 1.2^{* *}$ \\
\hline
\end{tabular}


On the 28th day of the experiment, the activity of the alanine aminotransferase in the serum of the diseased cows was higher by $25 \%$ in comparison with the control group of animals. Similar changes were found in the study of aspartate aminotransferase activity, where the blood of the experimental group of cows contained $306.2 \pm 15.9$ nkat $\mathrm{L}^{-1}$ on the 14 th day of the experiment, whereas in the control group this indicator was $270.0 \pm 16.2$ nkat $\mathrm{L}^{-1}$. The highest activity of the enzyme was on the $21 \mathrm{st}$ day of the experiment, compared to the control, it increased by $22 \%$.

It should also be noted that the activity of alanine aminotransferase in the blood of the sick cows increases largely than the activity of aspartate aminotransferase. This is evidently because the aspartate aminotransferase occurs in hepatocyte mitochondria, and in order to penetrate into the blood, it is necessary to penetrate through the membrane of mitochondria first and then through the cell membrane. High activity of AIAT and AsAT in the serum of the cows under experimental fascioliasis sensitized by atypical mycobacteria, indicates destructive processes in the liver that cause release of cellular organelles in the blood of amine transaminases. Thus, the results obtained indicate an increase in destructive processes in the body of the cows under experimental fascioliasis sensitized with atypical mycobacteria. It is important to study the activity of alkaline phosphatase in the blood of experimental animals, since it affects the process of calcium deposition in bone tissue, as well as transport and lipid metabolism. Alkaline phosphatase in serum is a general activity of its isoenzymes contained in the liver, bones, kidneys, intestinal mucosa and placenta. Increased activity of alkaline phosphatase was detected in the blood serum of experimental animals. It is possible that the reason for the increase in alkaline phosphatase activity was the negative effect of Fasciola and mycobacterium on the liver tissue and increased activity was due to hepatic isoenzyme. The activity of alkaline phosphatase increased from $42.3 \pm 1.2 \mathrm{Un} \mathrm{L}^{-1}$ to 50.1 $\pm 1.4 \mathrm{Un} \mathrm{L}^{-1}$, which is $18 \%$ more than in the control group of cows.

\section{Conclusion}

Under Fasciola invasion, the cows sensitized with mycobacteria undergo the suppression of the protein synthesis function of the, which manifests itself as a decrease in total blood protein, a decrease in the level of albumins and an increase in the level of globulins. According to the clinical manifestation of fascioliasis in the cows sensitized with atypical mycobacteria, pathogens of the diseases have a toxic effect on hepatocytes, causing an increase in the permeability of the biological membranes of the cell membranes. The indicated changes lead to an increase in the activity of blood serum enzymes, particularly, aminotransferases (AsAT and AIAT) and alkaline phosphatase.

\section{References}

Kulyaba, O., Stybel, V., \& Gutyj, B. (2017). The influence of closaverm a and catosal on indicators of protein synthesizing functions of cows liver by experimental fasciolosis, sentsitized by atypical mycobacteria. Scientific Messenger LNUVMBT named after S.Z. Gzhytskyj, 19(73), 122-125. doi: 10.15421/nvlvet7325

Dovgij, Ju.Ju., Vahovs'kyj, I.L., \& Semenenko, R.D. (2000). Zahvorjuvannja velykoi' rogatoi' hudoby, vyklykane parazytuvannjam fasciol v asociacii' z bakterijamy i grybamy. Visnyk Derzh. agroekol. akad. Ukrai'ny: Nauk.- teor. zb. -Zhytomyr. 2, 115-118 (in Ukrainian).

Kuljaba, O.V., Stybel, V.V., Gutyj, B.V. (2016). The influence of clozaverm A and catozal on antioxidant status of cows organism for the experimental fasciolosis, sensitized atypical mycobacteria. Scientific Messenger LNUVMBT named after S.Z. Gzhytskyj, 18, 2(66), 96-99. doi: $10.15421 /$ nvivet6621

Gorobey, O.M., Tarasenko, L.O., Khimich, M.S., Piven, O.T., Petrenko, O.V., \& Matviishyn, T.S. (2018). Monitoring of separate elements of the management system for the safety of slaughter products of small cattle. Scientific Messenger of Lviv National University of Veterinary Medicine and Biotechnologies, 20(92), 145-150. doi: 10.32718/nvlvet9230

Litvinov, V.I., Makarova, N.V., \& Krasnova, M.A. (2008). Netuberkuleznye mikobakterii. M.: MNPCBT (in Russian).

Vejsfeller, D. (1975). Biologija i izmenchivost' mikobakterij tuberkuleza i atipichnye mikobakterii: jeksperimental'nye i teoreticheskie issledovanija. Izd-vo AN Vengrii, Budapesht (in Russian).

Tkachenko, O., Glebenyuk, V., \& Glebenyuk, O. (2016). Efficiency by pcr detection dissociative variants mycobacterium bovis quickly growing strain. Scientific Messenger of LNU of Veterinary Medicine and Biotechnologies. Series: Veterinary Sciences, 18(1), 185-188.

Skrypnik, A.V. (2007). Primenenie molekuljarno-geneticheskih metodov dlja izuchenija vidovogo sootnoshenija mikobakterij, izolirovannyh v Ukraine ot reagirovavshego na tuberkulin KRS. Vet. Patologija, 4, 111-117 (in Russian).

Litvinov, V.I., Dorozhkova, I.R., Makarova, M.V., Krasnova, M.A., \& Frejman, G.E. (2010). Vydelenie i identifikacija netuberkuleznyh mikobakterij. Vestnik RAMN, 3, 7-11 (in Russian).

Kravciv, R.J., Kuljaba, O.V., Turko, I.B., \& Semanjuk, V.I. (2007). Osoblyvosti vmistu bilkiv syrovatky krovi tvaryn, kontaminovanyh mikobakterijamy. Naukovyj visnyk L'vivs'kogo nacional'nogo universytetu veterynarnoi' medycyny ta biotehnologij imeni S.Z. G'zhyc'kogo, 9, 4(35), 74-78 (in Ukrainian).

Vlizlo, V.V. (2012) Laboratorni metody doslidzhen u biologiyi, tvarynnycztvi ta veterynarnij medycyni: dovidnyk. Lviv: Spolom (in Ukrainian). Gutyj, B., Nazaruk, N., Levkivska, A., Shcherbatyj, A., Sobolev, A., Vavrysevych, J., Hachak, Y., Bilyk, O., Vishchur, V., Guta, Z. (2017). The influence of nitrate and cadmium load on protein and nitric metabolism in young cattle. Ukrainian Journal of Ecology, 7(2), 9-13. doi: $10.15421 / 2017 \quad 14$

Gutyj, B., Leskiv, K., Shcherbatyy, A., Pritsak, V., Fedorovych, V., Fedorovych, O., Rusyn, V., \& Kolomiiets, I. (2017). The influence of Metisevit on biochemical and morphological indicators of blood of piglets under nitrate loading. Regulatory Mechanisms in Biosystems, 8(3), 427-432. doi: 10.15421/021766

Gutyj, B., Grymak, Y., Drach, M., Bilyk, O., Matsjuk, O., Magrelo, N., Zmiya, M., \& Katsaraba, O. (2017). The impact of endogenous intoxication on biochemical indicators of blood of pregnant cows. Regulatory Mechanisms in Biosystems, 8(3), 438-443. doi: $10.15421 / 021768$.

Gutyj, B., Khariv, I., Binkevych, V., Binkevych, O., Levkivska, N., Levkivskyj, D., \& Vavrysevich, Y. (2017). Research on acute and chronic toxity of the experimental drug Amprolinsyl. Regulatory Mechanisms in Biosystems. 8(1), 41-45. doi: 10.15421/021708

Khariv, M.I., \& Gutyj, B.V. (2016). Vplyv liposomal'nogo preparatu Butaintervit na protei'nsyntezuval'nu funkciju pechinky shhuriv za otrujennja tetrahlormetanom. Visnyk Dnipropetrovs'kogo universytetu. Biologija, medycyna, 7(2), 123-126 doi:10.15421/021622 (in Ukrainian).

Khariv, M., Gutyj, B., Butsyak, V., \& Khariv, I. (2016). Hematolohichni pokaznyky orhanizmu shchuriv za umov oksydatsiinoho stresu ta za dii liposomalnoho preparatu [Hematological indices of rat organisms under conditions of oxidative stress and liposomal preparation action]. Biological Bulletin of Bogdan Chmelnitskiy Melitopol State Pedagogical University, 6 (1), 276-289. doi: 10.15421/201615 (in Ukrainian).

Khariv, M., Gutyj, B., Ohorodnyk, N., Vishchur, O., Khariv, I., Solovodzinska, I., Mudrak, D., Grymak, C., \& Bodnar, P. (2017). Activity of the $\mathrm{T}$ - and B-system of the cell immunity of animals under conditions of oxidation stress and effects of the liposomal drug. Ukrainian Journal of Ecology, 7(4), 536-541. doi: 10.15421/2017_157 
Martyshuk, T.V., Gutyj, B.V., \& Vishchur, O.I. (2016). Riven produktiv perekysnoho okysnennia lipidiv u krovi shchuriv za umov oksydatsiinoho stresu ta za dii liposomalnoho preparatu "Butaselmevit" [Level of lipid peroxidation products in the blood of rats under the influence of oxidative stress and under the action of liposomal preparation of "Butaselmevit"], Biological Bulletin of Bogdan Chmelnitskiy Melitopol State Pedagogical University, 6 (2), 22-27. doi: 10.15421/201631 (in Ukrainian).

Gutyj, B., Paska, M., Levkivska, N., Pelenyo, R., Nazaruk, N., \& Guta, Z. (2016). Study of acute and chronic toxicity of 'injectable mevesel' investigational drug. Biological Bulletin of Bogdan Chmelnitskiy Melitopol State Pedagogical University, 6(2), 174-180. doi: $10.15421 / 201649$.

Shcherbatyy, A. G., Slivinska, L. G., Gutyj, B. V., Golovakha, V. I., Piddubnyak, A. V., \& Fedorovuch, V. L. (2017). The influence of a mineral-vitamin premix on the metabolism of pregnant horses with microelemetosis. Regulatory Mechanisms in Biosystems, 8(2), 393-398. doi:10.15421/021746

Kryshtalska, M., Hunchak, V., \& Gutyj, B. (2017). Influence of the drug "Trifuzol" on the functional state of the liver in chickens for eymeriozic invasion. Scientific Messenger LNUVMBT named after S.Z. Gzhytskyj, 19(77), 76-79. doi:10.15421/nvlvet7718

Lavryshyn, Y.Y., Gutyj, B.V., Palyadichuk, O.R., \& Vishchur, V.Y. (2018). Morphological blood indices of bulls in experimental chronic cadmium toxicosis. Scientific Messenger of Lviv National University of Veterinary Medicine and Biotechnologies, 20(88), 108-114. doi: $10.32718 /$ nvlvet8820

Ostapyuk, A.Y., \& Gutyj, B.V. (2018). Influence of cadmium loading on morphological parameters of blood of the Laying Hens. Scientific Messenger of Lviv National University of Veterinary Medicine and Biotechnologies, 20(88), 48-52. doi: 10.32718/nvlvet8808.

Nazaruk, N., Gutyj, B.V., \& Hufriy, D. (2015). Influence of metifen and vitamix se on the activity of aminotransferases of bulls blood serum at cadmium nitrate loading. Scientific Messenger of LNU of Veterinary Medicine and Biotechnologies, 17(1), $121-126$.

\section{Citation:}

Kulyaba, O., Stybel, V., Gutyj, B., Turko, I., Peleno, R., Turko, Ya., Golovach, P., Vishchur, V., Prijma, O., Mazur, I., Dutka, V., Todoriuk, V., Golub, O. Dmytriv, O., Oseredchuk, R. (2019). Effect of experimental fascioliasis on the protein synthesis function of cow liver.

Ukrainian Journal of Ecology, 9(4), 612-615.

\begin{tabular}{|l|l}
$(\mathrm{cc}) \mathrm{EY}$ \\
$\mathrm{Er}$
\end{tabular} 